\title{
ダーモスコピーが診断に有用であったeruptive syringomaの2例
}

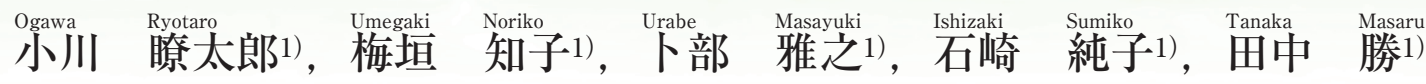

要 旨

Eruptive syringomaはsyringomaの1型であるが, 眼瞼に生じる eyelid typeと比べ, 比較的 稀である。今回我々はeruptive syringomaの2例を経験したのでダーモスコピー所見の特 徵について考察した。症例 $1 ： 21$ 歳男性. 19歳頃から躯幹の皮疹を自覚. 腋窩, 胸腹部に 褐色丘疹が多発し, 前医で扁平疮贅として加療されたが改善なく当科紹介となった。初診 時，臨床からDarier病を鑑別として考えた。症例 $2 ： 67$ 歳男性. 20代から全身に疼痒を伴 う皮疹を自覚していた。躯幹，四肢に褐色丘疹が多発。症例1および2のダーモスコピー所 見は, 境界明瞭な淡褐色のpigment networkを呈した。病理組織学的所見は軽度の表皮肥 厚と真皮内に管腔状に配列する上皮成分と膠原線維の増加あり，症例1および2とも体幹に 多発する褐色の扁平な小丘疹が多発する臨床と, 汗管様の管腔構造が増生した病理組織学 的所見を併せてeruptive syringomaと診断した。症例1で臨床的に鑑別を要した，扁平病贅， Darier病との比較を行った，汗管腫，扁平病贅，Darier病といずれも青年期に発症するこ とが多く, 褐色の扁平小丘疹を呈するが, 汗管腫では表面平滑で病変の境界がやや不明瞭 なのに対し, 扁平疮贅, Darier病では表面粗造で境界は明瞭である. ダーモスコピー所見 と病理組織学的所見を対比してみると, 汗管腫のダーモスコピー所見で見られた白色領域 は真皮網状層の膠原線維の増生に対応する，境界不明瞭であることは真皮内病変であるこ とに対応する。扁平疮贅のダーモスコピー所見は表皮肥厚に対応して境界は明瞭であり， 小点状血管がみられる。 Darier病のダーモスコピー所見では白色のhaloに囲まれた褐色領 域が見られ，褐色領域は過角化による角栓に対応する。汗管腫の角層は表面平滑で，扁平 疮贅とDarier病は表面粗造であり，その点をダーモスコピーで観察することがeruptive syringomaの診断に有用であると考えた.

Key words : 汗管腫 (syringoma), 発疹性汗管腫 (eruptive syringoma), ダーモスコ ピー (dermoscopy), 扁平疮贅 (verruca plana), Darier病（Darier’s disease)

\section{はじめに}

小川 瞭太郎 ${ }^{11}$ Ogawa Ryotaro

梅垣 知子 ${ }^{1)}$ Umegaki Noriko

卜部 雅之 ${ }^{1)}$ Urabe Masayuki

石崎 純子 ${ }^{1)}$ Ishizaki Sumiko

田中 勝 ${ }^{11}$ Tanaka Masaru

1）東京女子医科大学東医療センター 皮膚科

別刷請求先: 小川 瞭太郎

東京女子医科大学東医療センタ一皮膚科

干116-8567 東京都荒川区西尾久2-1-10

2021 年3月29日受付，2021年4月15日掲載決定
汗管腫は1872年にKaposiにより初めて報告さ れた，汗管の増生よりなる良性皮膚付属器腫瘍で ある ${ }^{1)}$. 発生部位別にeyelid type, eruptive syringoma, localized syringomaの3型に分類され る2). Eyelid typeはもっとも頻度が高く，中年女 性の下眼瞼に好発する ${ }^{3)}$. Localized syringomaは 
眼瞼以外の上肢屈側や外陰部に限局性に集簇して 生じるもっとも稀な型である ${ }^{3)}$. Eruptive syringomaは比較的稀で，小児期を含む青年期に 発症し胸部，腹部などの体幹前面に好発する ${ }^{4)}$. 集簇傾向があり，片側性に発症した例5，6) や， Blaschko線に沿う例など ${ }^{2)}$, 皮疹は様々な分布を 示す. 臨床所見はDarier病, 汗管囊腫, アミロイ ド苔㿏, 光沢苔癬, 多発皮膚線維腫など様々な疾 患と鑑別を要することがあり ${ }^{3)}$ 7), eruptive syringomaの6割が病理組織学的所見によって初 めて診断されたという報告もある ${ }^{8)}$. 病理組織学 的には真皮網状層に索状または管腔状に配列する 上皮細胞の増加がみられ，管腔構造の周囲に膠原 線維の増生がみられる。 今回我々はeruptive syringomaの2例を経験した。そのうち1例は褐色 扁平な丘疹が集族傾向をもって多発しており, 扁 平疮贅, Darier病との鑑別を要した。診断におけ るダーモスコピー所見の有用性を含めて報告する.

\section{症例 1}

患者 : 21歳, 男性.

主訴 : 全身の皮疹

既往歴：特記すべきことなし.

家族歴 : 同症なし.

現病歴：19歳頃から体幹に自覚症状のない褐色の 皮疹が出現し, 増大傾向を自覚していた。前医で 扁平疮贅を疑われ, 尿素クリーム外用, ヨクイニ ン内服, 液体窒素冷凍凝固の加療を受けたが, 改 善なく当科に紹介受診し た。

初診時現症：胸腹部, 両 側腋窩に集簇傾向のある 褐色丘疹が多発していた。 個疹は2 3 $\mathrm{mm}$ 大の扁平 な褐色小丘疹で角化傾向 はなく, 一部で融合傾向 があった（図1a,b).

\section{図1a 症例1 臨床像}

体幹, 両側腋窩に褐色の扁平な 小丘疹が多発し，集簇傾向がみ られる.

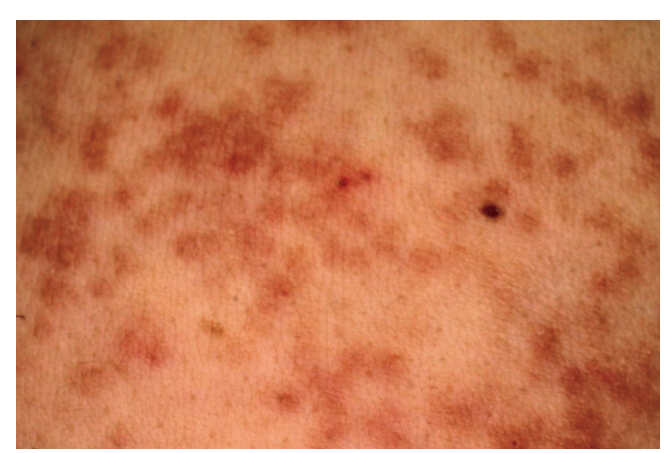

図1b 症例1 臨床拡大像

個疹は2 3 mm大の褐色の扁平な小丘疹で融合傾向もみら れる.

ダーモスコピー所見：淡褐色で不明暸な色素ネッ トワークがみられる. 病変部の背景は, 周囲の健 常部と比べてわずかに黄色みを带びた均一な白色 領域であった（図2a）。無偏光拡大像では病変内 にも周囲と同様の皮溝, 皮野が観察された（図 $2 b)$.

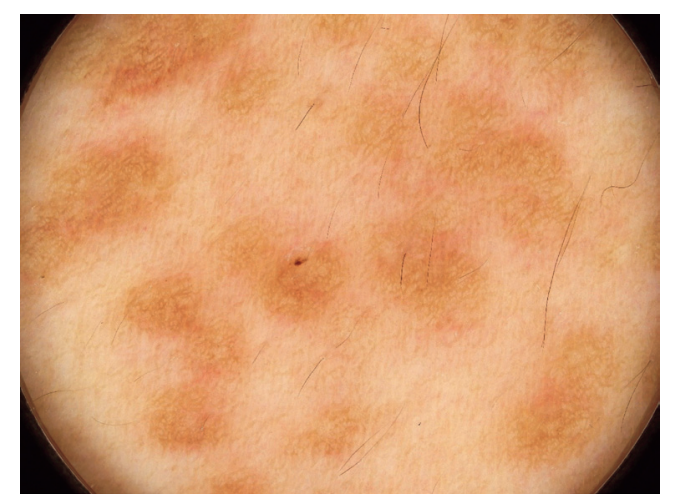

図2a＼cjkstart症例1 ダーモスコピー像

淡褐色の不明瞭な色素ネットワークがみられる. 病変部の 背景は, 周囲の健常部と比べてわずかに黄色みを帯びた均 一な白色領域である.

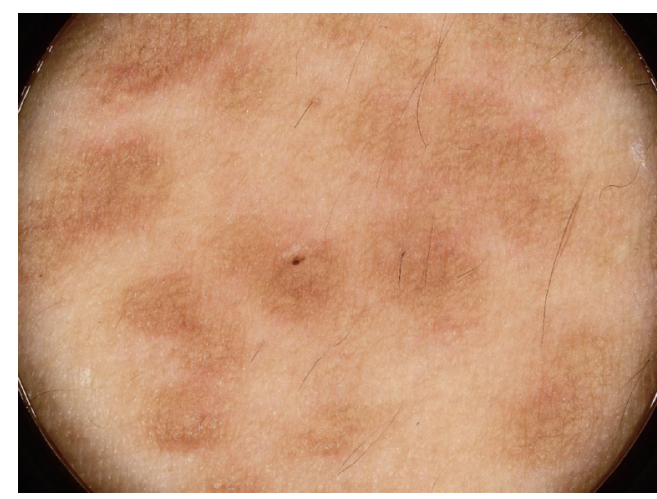

図2b 症例1 ダーモスコピー無偏光拡大像 境界は不明瞭で周囲と同様の皮溝, 皮野がみられる. 
臨床検査所見：AST $33 \mathrm{U} / \ell$, ALT $58 \mathrm{U} / \ell, \gamma$ -GTP $26 \mathrm{U} / \ell$, BUN $10.0 \mathrm{mg} / \mathrm{dl}$, Cre $0.87 \mathrm{mg} / \mathrm{dl}$, WBC $6800 / \mu \mathrm{l}$ (Neu $72.2 \%$, Eos $1.0 \%$, Bas $0.9 \%$, Mon $4.9 \%$, Lym 21.0\%), RBC $575 \times 10^{4} / \mu \mathrm{l}, \mathrm{Hb}$ $17.0 \mathrm{~g} / \mathrm{dl}$, Plt $20.8 \times 10^{4} / \mu \mathrm{l}$

病理組織学的所見：角層に明らかな異常なく, 表 皮では軽度の表皮索の延長があり，表皮索先端部 の基底層にはメラニン沈着がみられる。真皮網状 層に膠原線維の増生があり, その中に索状または 管腔状に配列する上皮細胞の増加がみられ，管腔 に連続して索状の上皮細胞がみられる特徴的なオ タマジャクシ様構造（tadpole appearance）も観 察された（図3a,b).

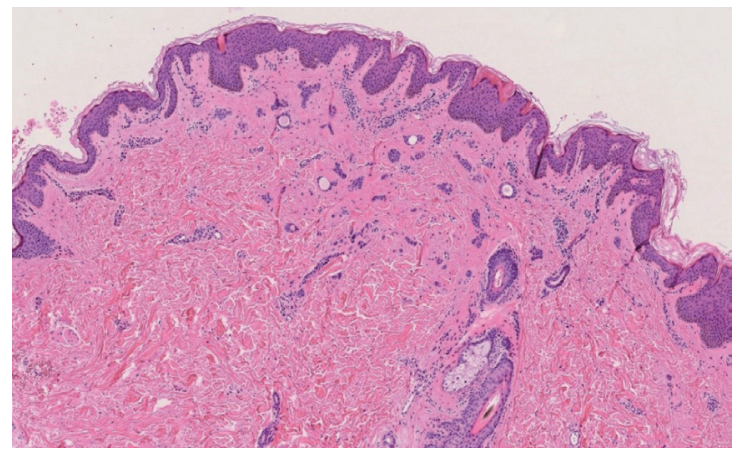

図3a 症例1 H-E染色 $\times 40$

軽度の表皮肥厚あり, 真皮浅層に増生する管腔構造と索状 上皮構造があり，その周囲には膠原線維の増生がみられる。

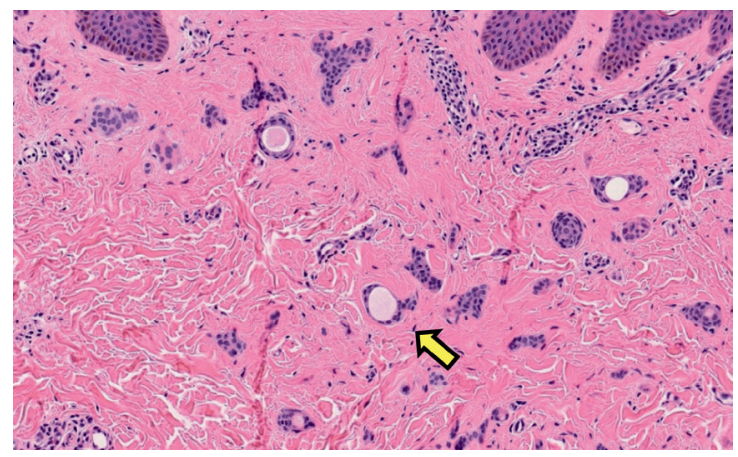

\section{図3b 症例 $1 \mathrm{H}-\mathrm{E}$ 染色 $\times 100$}

基底層にメラニンの沈着が軽度みられる. 真皮網状層に索 状または管腔状に配列する上皮細胞の増加があり，管腔に 連続して索状の上皮細胞がみられるオタマジャクシ様構造 （矢印）も確認された.

\section{症例2}

患者: 66歳, 男性.

\section{主訴：全身の皮疹}

既往歴：脂質異常症

家族歴 : 同症なし

現病歴：20歳代から瘙痒を伴う全身の皮疹を自覚 していた。一部では消退することもあった。これ まで皮膚科の受診歴はなかったが，前医内科で指 摘を受け，精查目的に当科紹介受診となった。

初診時現症：体幹, 四肢に淡い紅色から褐色調の 小型な扁平丘疹が多数散在していた（図4)。体幹 は背部より胸腹部に多く, 四肢では屈側より伸側 に多く分布していた，個疹は数mm大までの境界 やや不明瞭な褐色の小丘疹で，一部に融合傾向が みられた。

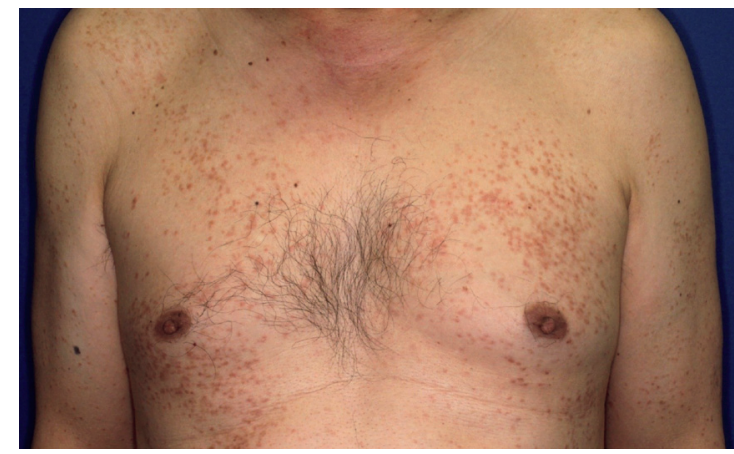

図4 症例2 初診時臨床像

体幹，四肢に褐色の扁平な小丘疹が散在していた.

ダーモスコピー所見：淡褐色の色素ネットワーク がみられる。病変部の背景は, 周囲の健常部と比 べてわずかに黄色みを带びた均一な白色領域であ った（図5).

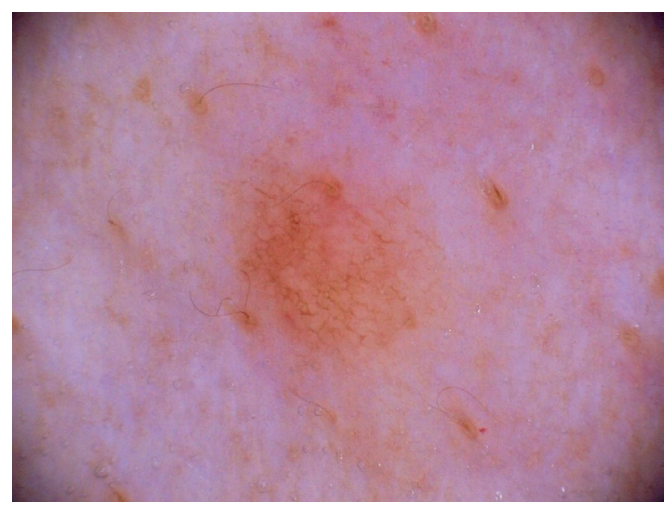

図5 症例2 ダーモスコピー像

淡褐色の色素ネットワークがみられる. 病変部の背景は, 周囲の健常部と比べてわずかに黄色みを帯びた均一な白色 領域である. 
臨床検査所見 : AST $23 \mathrm{U} / \ell$, ALT $23 \mathrm{U} / \ell, \gamma$ -GTP $58 \mathrm{U} / \ell$, BUN $16.0 \mathrm{mg} / \mathrm{dl}$, Cre $0.93 \mathrm{mg} / \mathrm{dl}$, WBC $4500 / \mu \mathrm{l}$ (Neu 57.0\%, Eos 2.0\%, Bas 0.4\%, Mon $6.0 \%$, Lym 34.6\%), RBC $467 \times 10^{4} / \mu \mathrm{l}, \mathrm{Hb}$ $14.3 \mathrm{~g} / \mathrm{dl}$, Plt $21.7 \times 10^{4} / \mu \mathrm{l}$

病理組織学的所見：角層に明らかな異常所見はな く，表皮では表皮突起の延長があり，表皮索先端 部の基底層にはメラニンの沈着がみられた。真皮 浅層に血管周囲性のリンパ球主体の炎症細胞浸潤 が軽度あり，真皮網上層に索状または管腔状に配 列する上皮細胞の増加がみられた。増加した上皮 細胞に異型性はない。 また，管腔構造の周囲には 膠原線維の増加がみられた（図6a，b).

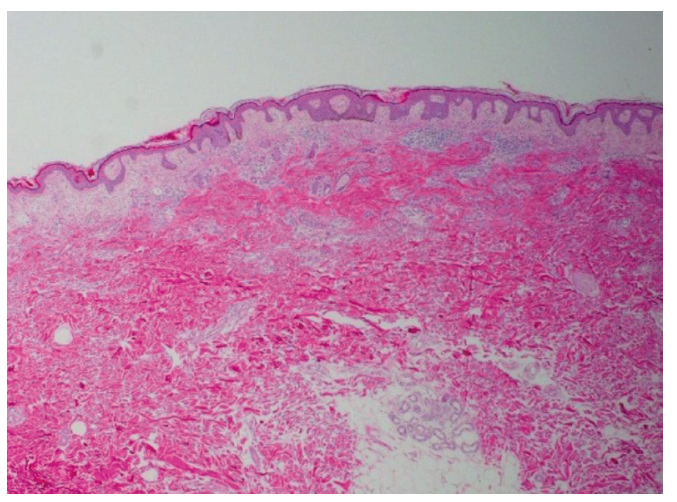

図6a 症例2 病理組織像 $(H-E$ 染色 $\times 20)$

軽度の表皮肥厚と基底層の色素沈着あり, 真皮網状層に膠 原線維の増生がみられる. 真皮浅層に血管周囲性の細胞浸 潤が軽度ある.

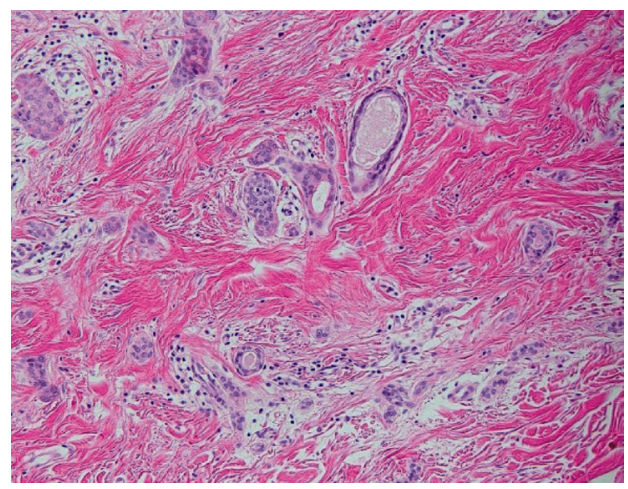

図6b H-E染色 $\times 100$

1層ないし数層の上皮細胞よりなる管腔構造がみられる.

診断：症例1は初診時にはDarier病, 扁平疮贅を 鑑別に考えた。症例 2 は初診時にeruptive syringomaと考えた。症例1, 2 ともに病理組織学 的に, eruptive syringomaと診断した.

\section{考 按}

Eruptive syringomaは比較的稀な汗管腫の1病 型である。松本らの本邦91例（1951～2002年）に ついての統計的検討によればeruptive syringoma の男女比は $1: 3$ と女性に多く, 発症年齢は 10 歳代 に最も高率にみられ，20歳代までに50\%が発症し ている，分布する部位については，体幹のみが $50.6 \%$ と最も多く，体幹に加えて四肢にも皮疹が 及ぶ例は $6.5 \%$ と比較的少ない ${ }^{4)}$. 自験例は, 症例

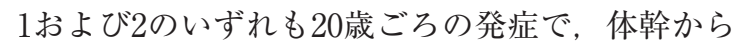
四肢に及ぶ広範囲に分布した。発症原因は未だ明 らかではないが，家族性発症の報告例 ${ }^{9)}$ やDown

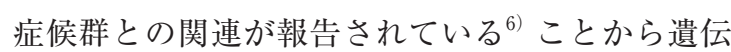
子変異の関連を示唆する報告や, 接触皮膚炎など の皮膚の炎症反応がエクリン汗腺の過形成を誘発 する可能性が示唆されている ${ }^{10)}$ ，汗管腫のダーモ スコピー所見は一様な淡褐色の局面, 部分的に微 細な褐色の色素ネットワーク, 多発性限局性色素 脱失などが報告されており ${ }^{3), 11)}$, 自験例でも同様 の所見がみられ診断に有用であった．病理組織学 的にも真皮に管腔状に配列する上皮細胞の増加が みられる点や周囲に線維化がみられる点は典型的 であった。

鑑別疾患としてはDarier病, 汗管囊腫, アミロ イド苔癬, 光沢苔癬, 多発皮膚線維腫などが挙げ られる。自験例の症例1では，青年期の発症で多 発する褐色の扁平な小丘疹が集簇傾向を呈した点 から，前医では扁平疮贅を疑われた。また，両腋 窩にも皮疹が分布したことからDarier病との鑑別 を要した。以下，この 2 疾患との鑑別を考察する. 扁平疮贅は青年期に多くみられ，手背や顔面に好 発する小豆大までの皮膚面よりわずかに隆起した 扁平丘疹が多発し，ときに融合したり，搔破によ って線状に配列するKöbner現象を伴うことが知 られているウイルス性疾患である ${ }^{12)}$ 。扁平疮贅の ダーモスコピー所見は褐色から淡紅色の背景に多 発性小点状血管がみられることが特徵である ${ }^{13)}$. 病理組織学的には若干の表皮肥厚, 過角化, 顆粒 層肥厚があり，顆粒層内の角化細胞の核はしばし ば腫大し，核のクロマチンは中心に位置し，その 
周囲に空胞化した核がみられる ${ }^{12)}$. Darier病は常 染色体優性遺伝形式をとる遺伝性角化症で 10～20 歳代に発症することが多い. 脂漏部や間擦部を中 心に, 直径 2 5 mm大の暗褐色の角化性丘疹が 多発し，融合して局面を形成する，ダーモスコピ 一所見としてはピンク色調な背景の中央に白色の haloに囲まれた黄色または褐色の領域が報告され ている ${ }^{14)}$. 病理所見は錯角化を伴う異常角化が特 徵で, 棘融解とそれに伴う裂隙の形成や真皮乳頭 が裂隙の中に突出して絨毛様を呈する。汗管腫と 扁平疮贅, Darier病を比較すると, 臨床像はいず れも集簇傾向のある褐色の扁平小丘疹を呈し, 思 春期に好発する。汗管腫は真皮内病変であるため 表面平滑で境界がやや不明瞭なのに対し, 扁平疥 贅, Darier病は表皮内病変のため表面が粗造で境 界は明瞭である。

次に, 病理組織学的所見とダーモスコピー所見 の関係について検討した。汗管腫のダーモスコピ ーでは白色領域と淡褐色の色素ネットワークがみ られるが, 白色領域は真皮網状層の膠原線維の増 生に対応しており, 淡褐色の色素ネットワークは 軽度に延長した表皮索先端部の基底層でみられた メラニン沈着に対応していた。 また, 境界不明瞭 であることや無偏光ルーペ像で皮溝, 皮野に変化 がないことは角層に異常がなく真皮内の病変であ ることに対応する. 対して, 扁平疮贅のダーモス コピー所見でみられる小点状血管は真皮乳頭層の 毛細血管に相当し，また境界明瞭であることは表 皮病変であることに対応する. Darier病のダーモ スコピー所見では中央の褐色領域は異常角化で形 成された角栓に対応し，それを囲む白色のhaloは 角栓を囲むように折れ込んだ表皮が真上から見る と厚くなるため白色を呈すると考えられる。

体幹部に多発する eruptive syringomaでは, 臨 床的に扁平疮贅やDarier病などと鑑別を要するが, ダーモスコピーを用いて表皮病変と真皮病変の違 いを考慮することで, 非侵襲的に汗管腫を想起す ることが可能であると考えた。

\section{文 献}

1) Kaposi M: Lehrbuch der Hautkrankheiten, Auflage, Bd2. 1872; 282.

2) Hashimoto K et al: Eruptive hidradenoma and syringoma. Histological, histochemical, and electron microscopic studies. Arch Dermatol 1967; 96: 500-519.

3 ) 原みずき, 川瀬 正昭, 江藤 隆史: eruptive syringoma の2例. 皮病診療 2018; 40: 493-496.

4 ) 松本京子ほか: eruptive syringomaの1例. 皮虐臨床 2002; 44: 87-89.

5 ) 佐藤良樹, 中村かおり, 寺木祐一：左乳輪周囲に片側性 にみられたEruptive Syringomaの1例. 皮膚臨床 2016; 58: 1908-1909.

6) 堀木 聡ほか：ダウン症候群と汗管腫の合併 片側分 布の1例と合併調查. 皮膚 1999; 41: 62-67.

7 ) 渡口美帆ほか：ダーモスコピーが診断に有用であった eruptive syringoma. 皮病診療 2016; 38: 299-302.

8 ) Soler-Carrillo J, Estrach T, Mascaró JM: Eruptive syringoma: 27 new cases and review of the literature. J Eur Acad Dermatol Venereol 2001; 15: 242-246.

9 ）浅賀浩孝ほか：家族性発疹性汗管腫. 臨皮 2001; 55: $428-430$.

10) Avhad G, Ghuge P, Jerajani HR: Generalized eruptive syringoma. Indian J Dermatol 2015; 60: 214.

11) Hayashi $Y$ et al: Unilateral linear syringoma in a Japanese female: dermoscopic differentiation from lichen planus linearis. Dermatol Reports 2011; 3: e42.

12）江川清文: 扁平疮贅; 玉置邦彦 ほか編, 最新皮虐科 学大系, 15卷, 中山書店, 東京, 2003, 78-80.

13）笹川征雄：脂漏性角化症との鑑別にダーモスコピーが 有用であった扁平疮贅. J Visual Dermatol 2007; 6: 256257.

14) Errichetti E et al: Dermoscopy of Darier's disease. J Eur Acad Dermatol Venereol 2016; 30: 1392-1394. 


\title{
Two cases of eruptive syringoma presenting with characteristic dermoscopic findings
}

\author{
Ryotaro Ogawa ${ }^{1)}$, Noriko Umegaki ${ }^{1)}$, Masayuki Urabe ${ }^{1)}$, Sumiko Ishizaki ${ }^{1)}$, Masaru Tanaka ${ }^{1)}$ \\ 1) Department of Dermatology, Tokyo Women's Medical University Medical Center East
}

Eruptive syringoma is a rare type of syringoma, a benign tumor of the eccrine ducts, and is characterized by the presence of widespread hyperpigmented papules on the trunk with onset around puberty. Here, we report two cases of eruptive syringoma presenting with characteristic dermoscopic findings.

Case 1 involved a 21-year-old man who had developed a widespread skin rash on his trunk around the age of 19 years. Clinical examination showed small brown papules spreading on the trunk and both axillae. The differential diagnoses included verruca plana and Darier's disease. Case 2 involved a 67-year-old man who had been aware of itchy brown papules on the trunk since he was in his twenties. Dermoscopy in cases 1 and 2 showed homogeneous light brown pigmentation with multifocal whitish areas and a delicate pigment network at the periphery, which are typical characteristics of eruptive syringoma. Histopathological examination showed numerous small ducts and islands of epithelium embedded in a fibrous stroma in the upper dermis. These findings were compatible with the diagnosis of eruptive syringoma in cases 1 and 2 .

On comparing the dermoscopic and histopathological findings of syringoma, the whitish area with unclear borders corresponded to the fibrous stroma in the upper dermis, and the unclear borders corresponded to the dermal lesion. Therefore, dermoscopy may be helpful to differentiate eruptive syringoma from other skin diseases that involve the presence of widespread hyperpigmented papules with intraepidermal lesions, such as verruca plana or Darier's disease. 